ANNA SKAWIŃSKA

The Kukasiewicz Research Network - Institute of Ceramics

and Building Materials, Division of Glass and Building Materials in Cracow

TOMASZ FOSZCZ

The Institute of Ceramics and Building Materials,

Department of Glass Technology in Cracow

e-mail: a.skawinska@icimb.pl
Manuscript submitted 2019.09.20 - revised 2019.10.04, initially accepted for publication 2019.11.13, published in December 2019

\title{
STUDY OF RUBBER GRANULES IMPACT ON SELECTED MECHANICAL PROPERTIES OF CEMENT MORTARS
}

\section{BADANIE WPŁYWU GRANULATU GUMOWEGO NA KSZTAŁTOWANIE WYBRANYCH WŁAŚCIWOŚCI MECHANICZNYCH ZAPRAW CEMENTOWYCH}

DOI: $10.30540 /$ sae-2019-019

\begin{abstract}
The ground rubber waste material from used vehicle tyres is used in road construction as well as in the cement industry. The use of granules in an amount of 5\% causes a decrease in strength by about $25 \%$. Replacement of $15 \%$ of cement by rubber waste is causing the reduction of strength by nearly $50 \%$. The research of the microstructure of mortars with rubber granules indicates the proper hydration reaction. Observation under scanning electron microscope of mortar with ground rubber waste has shown presence of $\mathrm{C}-\mathrm{S}-\mathrm{H}$ phase and portlandite. The presence of additional, porous zones of contact between the granulate and cement paste was also found
\end{abstract}

Keywords: ground rubber waste, mortar, strength

\section{Streszczenie}

Rozdrobnione odpady gumowe z zużtych opon samochodowych znajduja zastosowanie w budownictwie drogowym, jak również przemyśle cementowym. Artykut prezentuje wykorzystanie odpadów gumowych do modyfikacji zapraw cementowych. Zastosowanie granulatu w ilości $5 \%$ powoduje spadek wytrzymałości o około $20 \%$. Zastapienie cementu $15 \%$ odpadu gumowego przyczynia się do obniżenie wytrzymałości o blisko 50\%. Badania mikrostruktury zapraw z granulatem gumowym wskazuja na prawidlowy przebieg procesu hydratacji. Pod skaningowym mikroskopem elektronowym obserwuje się wtóknista fazę C-S-H oraz portlandyt. Stwierdzono również obecność dodatkowych, porowatych stref kontaktu granulatu z zaczynem.

Słowa kluczowe: rozdrobniony granulat gumowy, zaprawa, wytrzymałość

\section{INTRODUCTION}

The storage and management of rubber waste is becoming a huge global problem. In Poland, the use of this type of recyclables is a major problem. Currently, there are two groups of rubber waste, in which the first group includes vehicle tyres (about 70\%), the second group is industrial waste and conveyor belts (about 30\%) [1,2]. The Act of 14 December 2012 prohibits the disposal of tyres and their parts, excluding bicycle tyres and tyres with an external diameter greater than $140 \mathrm{~cm} \mathrm{[3].}$ Worn tyres are reconditioned, recycled or burned in cement plants. The European Union has imposed

\section{WSTĘP}

Ogromnym problemem światowym staje się składowanie i zagospodarowanie odpadów gumowych. W Polsce wykorzystanie tego typu surowców wtórnych stanowi duży problem. Wyróżnia się dwie grupy odpadów gumowych, pierwszą stanowią zużyte opony samochodowe (ok. 70\%), drugą odpady przemysłowe i taśmy przenośnikowe (ok. 30\%) [1, 2]. Ustawa z 14 grudnia 2012 r. zakazuje składowania na składowisku opon i ich części, z wyłączeniem opon rowerowych i opon o średnicy zewnętrznej większej niż $140 \mathrm{~cm}$ [3]. Zużyte opony poddawane są regeneracji, recyklingowi lub zostają spalone w cementowniach. Unia 
extended liability on tyre manufacturers, which means that they are responsible for the recovery of tyres, which should be $75 \%$ and recycling $15 \%$. The tyre recycling problem is a global issue with at least 7 million tonnes $(\mathrm{Mg})$ of more waste every year. Today it is estimated that there are more than M 29 $\mathrm{Mg}$ of worn tyres globally with $23 \%$ recycled. They are most often used in road construction and power engineering.

One of the solutions for the management of rubber waste is to build it into a cement matrix [4-10]. Scientific research focused on the use of ground rubber waste as a substitute for aggregate in concrete mix. The authors of the research indicate an improvement in workability and high deformability of cement composites. They also emphasize that the compressive strength of concrete made of rubber granules is decreasing. Due to the use of this concrete, inter alia, in road construction as jersey concrete road barriers and in rail transport as railroad ties, compressive strength is a secondary parameter [4-13].

Ganijan and et al. [4] used rubber granules as a substitute for cement. On the basis of the research they found that the compressive strength of mortars depends on two factors: the size of rubber granules and its quantity. Replacement of cement with 5\% rubber granules did not contribute to a significant decrease in compressive strength. Further increase in the amount of granules to $7.5 \%$ and $10 \%$ decreased the compressive strength after 28 days by $20 \%$ and $40 \%$, respectively.

The paper presents the results of laboratory tests of cement mortars modified with different content of rubber granules. An attempt to use rubber granules as a substitute for cement was made with the use of this waste in building materials in mind. The scope of research covered testing of physical properties, mainly in terms of compressive strength. The paper presents the microstructure of mortars with rubber granules.

\section{MATERIALS AND TEST METHODOLOGY}

CEM I 42 R; CEM II/B-V 32.5 R; CEM III/A 32.5 $\mathrm{N}$ and CEM IV/B-V $32.5 \mathrm{~N}$ were used as a binder for cement mortars. Chemical composition of cements is presented in Table 1. Standardized sand was used as aggregate in line with PN-EN 196-1 standard. A constant water-cement ratio of $0.5(\mathrm{~W} / \mathrm{C}=0.5)$ was maintained.
Europejska narzuciła na producentów opon rozszerzoną odpowiedzialność, oznacza to, że odpowiadają oni za odzysk opon, który powinien wynosić $75 \%$, a recykling $15 \%$. Co roku przybywa co najmniej $7 \mathrm{mln}$ ton $(\mathrm{Mg})$ odpadów. Obecnie szacuje się, że na świecie zużytych opon jest ponad $29 \mathrm{mln} \mathrm{Mg,} \mathrm{z} \mathrm{których} \mathrm{23 \%}$ ulega recyklingowi. Najczęściej wykorzystuje się je $\mathrm{w}$ budownictwie drogowym oraz $\mathrm{w}$ energetyce.

Jednym z rozwiązań zagospodarowania odpadów gumowych jest wbudowanie ich w matrycę cementową [4-10]. Badania skupiały się na wykorzystaniu rozdrobnionych odpadów gumowych jako zamiennika kruszywa w mieszance betonowej. Autorzy badań wskazują na poprawę urabialności oraz dużą odkształcalność kompozytów cementowych. Podkreślają również, że następuje spadek wytrzymałości na ściskanie betonów wykonanych $\mathrm{z}$ granulatem gumowym. $\mathrm{Z}$ uwagi na zastosowanie tego betonu, między innymi w budownictwie drogowym, jako bariery drogowe „Jersey”, oraz w transporcie kolejowym jako podkład kolejowy, wytrzymałość na ściskanie jest parametrem drugorzędnym [4-13].

Ganijan i inni [4] zastosowali granulat gumowy jako zamiennik cementu. Stwierdzili, że wytrzymałość na ściskanie zapraw cementowych zależy od: wielkości granulatu gumowego oraz od jego ilości. Zastąpienie cementu 5\% granulatu gumowego nie przyczyniło się do znacznego obniżenia wytrzymałości na ściskanie. Dalsze zwiększanie ilości granulatu do 7,5\% i 10\% spowodowało spadek wytrzymałości na ściskanie po 28 dniach odpowiednio o $20 \%$ i $40 \%$.

$\mathrm{W}$ artykule zaprezentowano wyniki badań laboratoryjnych zapraw cementowych modyfikowanych różną zawartością granulatu gumowego. Próba zastosowania granulatu gumowego jako zamiennika cementu została podjęta $\mathrm{z}$ uwagi na możliwość zagospodarowania tego odpadu w materiałach budowlanych. Zakresem badań zostały objęte badania właściwości fizycznych głównie pod kątem wytrzymałości na ściskanie. W artykule przedstawiono mikrostrukturą zapraw z granulatem gumowym.

\section{MATERIALY I METODY BADAŃ}

Do wykonania zapraw cementowych jako spoiwo wykorzystano cementy powszechnego użytku CEM I 42 R; CEM II/B-V 32,5 R; CEM III/A 32,5 N oraz CEM IV/B-V 32,5 N. Skład chemiczny cementów został przedstawiony w tabeli 1 . Jako kruszywo zastosowano piasek normowy spełniający wymagania normy PN-EN 196-1. Zachowano stały stosunek wodno-cementowy, który wyniósł $0,5(\mathrm{~W} / \mathrm{C}=0,5)$. 
Table 1. Chemical composition of cement

Tabela 1. Skład chemiczny cementu

\begin{tabular}{|c|c|c|c|c|}
\hline Properties & CEM I 42.5 R & CEM II/B-V 32.5 R & CEM III/A 32.5 N & CEM IV/B-V 32.5 N \\
\hline Calcination losses & $2.63 \pm 0.08$ & $2.68 \pm 0.08$ & $1.05 \pm 0.08$ & $2.08 \pm 0.08$ \\
\hline $\mathrm{SiO}_{2}$ & $19.65 \pm 0.2$ & $30.21 \pm 0.2$ & $32.57 \pm 0.2$ & $30.08 \pm 0.2$ \\
\hline $\mathrm{Al}_{2} \mathrm{O}_{3}$ & $4.87 \pm 0.26$ & $10.85 \pm 0.26$ & $7.67 \pm 0.26$ & $12.84 \pm 0.26$ \\
\hline $\mathrm{Fe}_{2} \mathrm{O}_{3}$ & $2.43 \pm 0.19$ & $3.68 \pm 0.19$ & $2.08 \pm 0.19$ & $4.14 \pm 0.19$ \\
\hline $\mathrm{CaO}$ & $64.68 \pm 0.30$ & $46.18 \pm 0.30$ & $48.68 \pm 0.30$ & $40.33 \pm 0.30$ \\
\hline $\mathrm{MgO}$ & $1.21 \pm 0.2$ & $1.66 \pm 0.2$ & $4.16 \pm 0.2$ & $1.66 \pm 0.2$ \\
\hline $\mathrm{SO}_{3}$ & $3.11 \pm 0.14$ & $2.14 \pm 0.14$ & $1.75 \pm 0.14$ & $2.87 \pm 0.14$ \\
\hline $\mathrm{Na}_{2} \mathrm{O}$ & $0.13 \pm 0.02$ & $0.48 \pm 0.02$ & $0.33 \pm 0.02$ & $0.63 \pm 0.02$ \\
\hline $\mathrm{K}_{2} \mathrm{O}$ & $0.73 \pm 0.04$ & $1.17 \pm 0.04$ & $0.53 \pm 0.04$ & $1.42 \pm 0.04$ \\
\hline $\mathrm{Na}_{2} \mathrm{O}_{\text {eqw.ropp }}$ & 0.61 & 1.25 & 0.68 & 1.56 \\
\hline
\end{tabular}

The modifying component was ground rubber waste from worn vehicle tyres. Rubber granules with 0-0.8 $\mathrm{mm}$; 0.6-2.0 mm; 1-4 $\mathrm{mm}$ and 2.5-6 $\mathrm{mm}$ grain-size was used as a substitute for cement in amounts of $5 \%$ and $15 \%$ (mass percentage). The content of heavy metals in the rubber granules was examined and the results are presented in Table 2.

\begin{tabular}{|c|c|}
\hline Heavy metals & $\begin{array}{l}\text { Heavy metal content in the extract of rubber } \\
\text { granules } 0-0.08 \mathrm{~mm}[\mathrm{mg} / \mathrm{l}] \text { grain size }\end{array}$ \\
\hline Beryllium & $<0.00005$ \\
\hline Vanadium & 0.00014 \\
\hline Chromium & 0.00006 \\
\hline Manganese & 0.134 \\
\hline Cobalt & 0.037 \\
\hline Nickel & 0.00208 \\
\hline Copper & $<0.00005$ \\
\hline Zinc & 3.04 \\
\hline Arsenic & $<0.00005$ \\
\hline Selenium & 0.00828 \\
\hline Molybdenum & 0.00096 \\
\hline Cadmium & $<0.00005$ \\
\hline Atimony & 0.00068 \\
\hline Barium & 0.0298 \\
\hline Thallium & $<0.00005$ \\
\hline Lead & 0.00012 \\
\hline Mercury & $<0.0007$ \\
\hline $\mathrm{pH}$ & 7.3 \\
\hline
\end{tabular}

Składnikiem modyfikującym były rozdrobnione odpady gumowe pochodzące ze zużytych opon samochodowych. Granulat gumowy o frakcji $0-0,8 \mathrm{~mm}$; 0,6-2,0 mm; 1-4 mm oraz 2,5-6 mm stosowany był jako zamiennik cementu w ilości 5\% i 15\% (procent masowy). W granulacie gumowym zbadano zawartość metali ciężkich, a wyniki zamieszczono w tabeli 2 .

Table 2. Heavy metal content in the extract of rubber granules

Tabela 2. Zawartość metali ciężkich w wyciagu z granulatu gumowego 
The basic components of tyres are ( $\%$ mass/tyre): rubber $25 \%$, silica $13 \%$, soot $6 \%$, sulphur $0.7 \%$, zinc white $0.7 \%$, activators $0.5 \%$. The remaining part consists of metal cord, textile fibres and others, which constitute $53.5 \%$.

The presence of heavy metals in tyres is related to the technological process. Zinc oxide $\mathrm{ZnO}$ is added directly to the production of the mix. The proportion of this oxide varies from $0.5 \%$ to $4 \%$ depending on the mix. The presence of antimony in water extract is associated with the addition of a flame retardant agent during the production of rubber, while cobalt salts are used as an adhesive. Other metals may come from bead wires, wire cords and polymerization catalysts.

Mixtures were prepared with cement replaced in the amount of $5 \%$ and $15 \%$ for each of the grain-size of rubber granules and for each cement.

The dosing of ingredients and the mixing time were in the following order. Cement and water are put in a stationary mixer. Rubber granules were added with the binder. After thirty seconds, standardized sand is placed where the mixing lasts thirty seconds. The mixing process is followed by manual homogenization and then restarting for 60 seconds.

An example of the mix composition is given in Table 3. Mortars with $5 \%$ and $15 \%$ of rubber granules of a grain-size of $0-0.8 \mathrm{~mm} ; 0.6-2.0 \mathrm{~mm} ; 1-4 \mathrm{~mm}$ and 2.5-6 mm were used for each type of cement. After the standardized $4 \times 4 \times 4 \times 16 \mathrm{~cm}$ mortar bars were formed, the compressive strength tests were performed after 2, 7 and 28 days.

Table 3. Determination of mixes and their composition Tabela 3. Oznaczenie mieszanek oraz ich skład

\begin{tabular}{|c|c|c|c|}
\hline \multirow{2}{*}{ Composition [g] } & \multicolumn{3}{|c|}{ Cement estimation } \\
\cline { 2 - 4 } & CEM I 42.5 R & CEM I 42.5 R + 5\% rubber granules & CEM I 42.5 R + 15\% rubber granules \\
\hline Cement & 450 & 427.5 & 382.5 \\
\hline Standardized sand & 1350 & 1350 & 67.5 \\
\hline Rubber waste & - & 22.5 & 225 \\
\hline Water & 225 & 225 & 250 \\
\hline
\end{tabular}

Podstawowymi komponentami opon są ( $\%$ mas./ oponę): kauczuk $25 \%$, krzemionka $13 \%$, sadza $6 \%$, siarka $0,7 \%$, biel cynkowa $0,7 \%$, aktywatory $0,5 \%$. Pozostałą część stanowi między innymi metalowy kord, włókna tekstylne i inne, które stanowią 53,5\%.

Obecność metali ciężkich w oponach związana jest z procesem technologicznym. Bezpośrednio do produkcji mieszanki dodaje się tlenek cynku - ZnO. Udział tego tlenku waha się w zależności od mieszanki w granicach od 0,5\% do 4\%. Obecność antymonu $\mathrm{w}$ wyciągu wodnym wiąże się z dodatkiem podczas produkcji środka utrudniającego palenie się gumy, natomiast sole kobaltu stosowane są jako środek adhezyjny. Pozostałe metale mogą pochodzić z drutów z drutówki, stalowych nici opasających oraz katalizatorów polimeryzacji.

Dla każdej z frakcji granulatu gumowego i dla każdego cementu przygotowano mieszanki, w których cement zastępowany był w ilości $5 \%$ oraz $15 \%$.

Dozowanie składników oraz czas mieszania odbywał się w następującej kolejności. W mieszarce stacjonarnej umieszcza się cement z wodą. Granulat gumowy wprowadzany był razem ze spoiwem. Po trzydziestu sekundach umieszcza się piasek normowy, gdzie mieszanie trwa trzydzieści sekund. Po zakończeniu procesu mieszania następuję ręczne homogenizowanie, a następnie ponowne uruchomienie na 60 sekund.

Przykładowy skład mieszanek przedstawiono w tabeli 3. Dla każdego rodzaju cementu wykonano zaprawy z $5 \%$ oraz $15 \%$ granulatu gumowego o frakcji 0-0,8 mm; 0,6-2,0 mm; 1-4 mm oraz 2,5-6 mm. Po zaformowaniu beleczek normowych o wymiarach $4 \times 4 \times 16 \mathrm{~cm}$ wykonano badania wytrzymałości na ściskanie po 2,7 i 28 dniach. 
Compressive strength tests of standardized mortar and mortar with rubber granules were performed according to PN-EN 196-1:2016-07. Heavy metal estimations were performed using the inductively coupled plasma mass spectrometry method (ICPMS) in accordance with PN-EN ISO 17294-2:201611 , from a previously prepared water extract prepared in accordance with PN-EN 12457-4:2006. The observations of the microstructure were made under the scanning electron microscope Thermo Scientific, Quattro S. The EDS chemical composition analysis was performed with the use of EDAX detector.

\section{REVIEW OF FINDINGS}

Table 4 shows the average compressive strength of mortars made from Portland cement CEM I 42.5 R with rubber granules after 2,7 and 28 days.
Badania wytrzymałości na ściskanie zaprawy normowej oraz $\mathrm{z}$ granulatem gumowym wykonano według PN-EN 196-1:2016-07. Oznaczenia metali ciężkich wykonano przy pomocy metody spektrometrii mas $\mathrm{w}$ plazmie indukcyjnie sprzężonej (ICP-MS) zgodnie z normą PN-EN ISO 17294-2:2016$11, \mathrm{z}$ uprzednio przygotowanego wyciągu wodnego wykonanego zgodnie z normą PN-EN 12457-4:2006. Obserwacje mikrostruktury wykonano pod elektronowym mikroskopem skaningowym Thermo Scientific, model Quattro S. Analizę składu chemicznego EDS wykonano z zastosowaniem detektora firmy EDAX

\section{WYNIKI BADAŃ I ICH OMÓWIENIE}

W tabeli 4 została przedstawiona średnia wytrzymałość na ściskanie zapraw wykonanych z cementu portlandzkiego CEM I 42,5 R z granulatem gumowym po 2,7 i 28 dniach.

Table 4. Compressive strength of CEM I 42.5 R mortars with rubber granules Tabela 4. Wytrzymałość na ściskanie zapraw CEM I 42,5 R z granulatem gumowym

\begin{tabular}{|c|c|c|c|}
\hline \multirow{2}{*}{ Test results } & \multicolumn{3}{|c|}{ Compressive strength [MPa] } \\
\hline & 2 days & 7 days & 28 days \\
\hline CEM I 42.5 R & $28.1 \pm 0.4$ & $46.4 \pm 1.0$ & $58.4 \pm 0.8$ \\
\hline CEM I 42.5 R 5\% 0-0.08 mm & $20.3 \pm 0.4$ & $34.7 \pm 0.3$ & $40.9 \pm 1.1$ \\
\hline CEM I 42.5 R 5\% 0.6-2 mm & $21.6 \pm 0.1$ & $36.8 \pm 0.8$ & $43.5 \pm 0.9$ \\
\hline CEM I 42.5 R 5\% 1-4 mm & $21.9 \pm 0.3$ & $36.0 \pm 0.8$ & $44.9 \pm 1.7$ \\
\hline CEM I 42.5 R 5\% 2.5-6 mm & $22.4 \pm 0.4$ & $36.8 \pm 0.8$ & $43.6 \pm 1.8$ \\
\hline CEM I 42.5 R 15\% 0-0.08 mm & $11.3 \pm 0.3$ & $21.1 \pm 1.4$ & $25.5 \pm 0.9$ \\
\hline CEM I 42.5 R 15\% 0.6-2 mm & $12.8 \pm 0.2$ & $23.1 \pm 0.6$ & $28.2 \pm 0.5$ \\
\hline CEM I 42.5 R 15\% 1-4 mm & $14.1 \pm 0.2$ & $23.7 \pm 0.8$ & $30.1 \pm 1.3$ \\
\hline CEM I 42.5 R $15 \%$ 2.5-6 mm & $14.4 \pm 0.2$ & $24.3 \pm 1.5$ & $29.4 \pm 1.9$ \\
\hline
\end{tabular}

Table 4 shows that the highest compressive strength of a mortar with $5 \%$ granules was obtained for fractions of 1-4 $\mathrm{mm}$ after 28 days and was 44.9 $\mathrm{MPa}$. The lowest strength after 28 days was obtained for CEM I $42.5 \mathrm{R}$ with the addition of $5 \%$ rubber granules of 0-0.08 mm grain-size. The compressive strength in this test was $40.9 \mathrm{MPa}$. The following compressive strength values of $43.5 \mathrm{MPa}$ and 43.6 MPa were obtained for other mortars made of $5 \%$ rubber granules of 0.6-2 $\mathrm{mm}$ and 2.5-6 $\mathrm{mm}$ grain-size. For mortars with the addition of $15 \%$ rubber granules, a lower compressive strength by $50 \%$ is observed in comparison with the standardized mortar after 2, 7 and 28 days.

Table 5 shows the compressive strength of mortars based on CEM II/B-V 32.5 R with rubber granules.
Z tabeli 4 wynika, że największą wytrzymałość na ściskanie zaprawy $\mathrm{z}$ dodatkiem $5 \%$ granulatu otrzymano dla frakcji 1-4 mm po 28 dniach, która wyniosła 44,9 MPa. Najniższą wytrzymałość po 28 dniach uzyskano dla CEM I 42,5 R z dodatkiem 5\% granulatu gumowego o frakcji 0-0,08 mm. Wytrzymałość na ściskanie dla tej próby wyniosła 40,9 $\mathrm{MPa}$. Dla pozostałych zapraw z 5\% granulatu gumowego o frakcji 0,6-2 mm i 2,5-6 mm uzyskano następujące wytrzymałości na ściskanie: 43,5 MPa i 43,6 MPa. Dla zapraw z dodatkiem $15 \%$ granulatu gumowego obserwuje się o $50 \%$ niższą wytrzymałość na ściskanie w porównaniu z zaprawą normową po 2,7 i 28 dniach.

W tabeli 5 przedstawiono wytrzymałość na ściskanie zapraw na bazie CEM II/B-V 32,5 R z granulatem gumowym. 
Table 5. Compressive strength of CEM II/B-V32.5 R mortars with rubber granules Tabela 5. Wytrzymatość na ściskanie zapraw CEM II/B-V32,5 R z granulatem gumowym

\begin{tabular}{|l|c|c|c|}
\hline \multirow{2}{*}{\multicolumn{1}{c|}{ Test results }} & \multicolumn{2}{c|}{ Compressive strength [MPa] } \\
\cline { 2 - 4 } & $\mathbf{2 ~ d a y s}$ & $\mathbf{7}$ days & $\mathbf{2 8}$ days \\
\hline CEM II/B-V 32.5 R & $17.5 \pm 0.3$ & $30.9 \pm 0.5$ & $42.1 \pm 0.7$ \\
\hline CEM II/B-V 32.5 R 5\% 0-0.08 mm & $12.9 \pm 0.2$ & $23.2 \pm 0.3$ & $32.0 \pm 0.4$ \\
\hline CEM II/B-V 32.5 R 5\% 0.6-2 mm & $13.5 \pm 0.1$ & $23.6 \pm 0.3$ & $32.7 \pm 0.6$ \\
\hline CEM II/B-V 32.5 R 5\% 1-4 mm & $13.3 \pm 0.2$ & $23.8 \pm 0.6$ & $33.2 \pm 1.0$ \\
\hline CEM II/B-V 32.5 R 5\% 2.5-6 mm & $13.4 \pm 0.1$ & $23.4 \pm 0.5$ & $33.1 \pm 0.7$ \\
\hline CEM II/B-V 32.5 R 15\% 0-0.08 mm & $6.4 \pm 0.1$ & $12.4 \pm 0.3$ & $16.3 \pm 0.2$ \\
\hline CEM II/B-V 32.5 R 15\% 0.6-2 mm & $8.2 \pm 0.1$ & $15.8 \pm 0.3$ & $21.2 \pm 0.5$ \\
\hline CEM II/B-V 32.5 R 15\% 1-4 mm & $8.3 \pm 0.2$ & $16.5 \pm 0.5$ & $23.3 \pm 1.0$ \\
\hline CEM II/B-V 32.5 R 15\% 2.5-6 mm & $8.7 \pm 0.1$ & $16.5 \pm 0.8$ & $23.4 \pm 1.8$ \\
\hline
\end{tabular}

Table 5 shows that the compressive strength of mortars with the addition of $5 \%$ rubber granulates of 0-0.8 $\mathrm{mm}$; 0.6-2 $\mathrm{mm} ; 1-4 \mathrm{~mm}$ and 2.5-6 $\mathrm{mm}$ grainsize is at a similar level. The compressive strength after 28 days for these mortars was $32.0 \mathrm{MPa}, 32.7$ $\mathrm{MPa}, 33.2 \mathrm{MPa}$ and $33.1 \mathrm{MPa}$. Similarly to CEM I $42.5 \mathrm{R}$ mortar, the lowest strength was obtained for mortars in which cement was replaced with $15 \%$ of rubber granules. The decrease in compressive strength was lower by $25.8 \mathrm{MPa}(0-0.08 \mathrm{~mm}), 20.9$ MPa (0.6-2), 18.8 MPa (1-4 mm) and 18.7 MPa (2.5-6 mm) for the CEM II/B-V $32.5 \mathrm{R}$ mortar after 28 days.
Z tabeli 5 wynika, że wytrzymałość na ściskanie zapraw $\mathrm{z}$ dodatkiem $5 \%$ granulatu gumowego o frakcji 0-0,8 mm; 0,6-2 mm; 1-4 mm i 2,5-6 mm jest na podobnym poziomie. Wytrzymałość na ściskanie po 28 dniach dla tych zapraw była następująca: 32,0 MPa, 32,7 MPa, 33,2 MPa i 33,1 MPa. Podobnie jak dla zaprawy CEM I 42,5 R najniższe wytrzymałości uzyskano dla zapraw, w których cement zastąpiono $15 \%$ granulatu gumowego. Spadek wytrzymałości na ściskanie był niższy o $25,8 \mathrm{MPa}(0-0,08 \mathrm{~mm})$, $20,9 \mathrm{MPa}(0,6-2 \mathrm{~mm}), 18,8 \mathrm{MPa}(1-4 \mathrm{~mm})$ i $18,7 \mathrm{MPa}$ (2,5-6 mm) w odniesieniu do zaprawy CEM II/B-V $32,5 \mathrm{R}$ po 28 dniach.

Table 6. Compressive strength of CEM III/A $32.5 \mathrm{~N}$ mortars with rubber granules Tabela 6. Wytrzymatość na ściskanie zapraw CEM III/A 32,5 N z granulatem gumowym

\begin{tabular}{|c|c|c|c|}
\hline \multirow{2}{*}{ Test results } & \multicolumn{3}{|c|}{ Compressive strength [MPa] } \\
\hline & 2 days & 7 days & 28 days \\
\hline CEM III/A $32.5 \mathrm{~N}$ & $9.8 \pm 0.1$ & $21.5 \pm 0.6$ & $33.7 \pm 0.7$ \\
\hline CEM III/A 32.5 N 5\% 0-0.08 mm & $7.8 \pm 0.2$ & $15.3 \pm 0.4$ & $25.7 \pm 0.8$ \\
\hline CEM III/A 32.5 N 5\% 0.6-2 mm & $7.5 \pm 0.1$ & $16.1 \pm 0.4$ & $26.5 \pm 0.8$ \\
\hline CEM III/A 32.5 N 5\% 1-4 mm & $8.4 \pm 0.2$ & $17.1 \pm 0.4$ & $26.6 \pm 0.9$ \\
\hline CEM III/A 32.5 N 5\% 2.5-6 mm & $8.3 \pm 0.1$ & $17.1 \pm 0.7$ & $27.2 \pm 1.4$ \\
\hline CEM III/A $32.5 \mathrm{~N} 15 \% 0-0.08 \mathrm{~mm}$ & $4.0 \pm 0.1$ & $8.7 \pm 0.2$ & $12.6 \pm 0.3$ \\
\hline CEM III/A 32.5 N 15\% 0.6-2 mm & $4.1 \pm 0.1$ & $9.6 \pm 0.2$ & $16.5 \pm 0.5$ \\
\hline CEM III/A 32.5 N 15\% 1-4 mm & $4.6 \pm 0.1$ & $11.4 \pm 0.7$ & $18.1 \pm 0.8$ \\
\hline CEM III/A 32.5 N 15\% 2.5-6 mm & $4.6 \pm 0.1$ & $10.9 \pm 0.6$ & $18.5 \pm 0.9$ \\
\hline
\end{tabular}

For the mortar based on CEM III/A $32.5 \mathrm{~N}$ cement a similar relationship can be observed as for the mortar based on CEM I $42.5 \mathrm{R}$ and CEM II/B-V $32.5 \mathrm{R}$. The lowest strength is achieved for tests with the
Dla zaprawy wykonanej na cemencie CEM III/A 32,5 N obserwuje się podobną zależność jak zapraw na bazie CEM I 42,5 R i CEM II/B-V 32,5 R. Najniższą wytrzymałość uzyskuje się dla prób z dodat- 
addition of $15 \%$ rubber granules. The compressive strength of the standard mortar was $33.7 \mathrm{MPa}$ after 28 days. For mortar with the addition of $5 \%$ rubber granules of 0-0.8 $\mathrm{mm}, 0.6-2 \mathrm{~mm}, 1-4 \mathrm{~mm}$ and 2.5 $6 \mathrm{~mm}$ grain-size, the compressive strength after 28 days was as follows: 25.7 MPa, 26.5 MPa, 26.6 MPa and $27.2 \mathrm{MPa}$. For mortars with $15 \%$ rubber granules, the compressive strength was as follows: $12.6 \mathrm{MPa}$ for 0-0.08 mm grain-size, 16.5 MPa for 0.6-2.0 mm grain-size, $18.1 \mathrm{MPa}$ for 1-4 mm grain-size and 18.5 $\mathrm{MPa}$ for 2.5-6 mm grain-size. kiem 15\% granulatu gumowego. Wytrzymałość na ściskanie zaprawy wzorcowej wyniosła $33,7 \mathrm{MPa}$ po 28 dniach. Dla zaprawy z dodatkiem $5 \%$ granulat gumowego o frakcji 0-0,8 mm; 0,6-2 mm; 1-4 mm i 2,5$6 \mathrm{~mm}$ wytrzymałość na ściskanie po 28 dniach była następująca: 25,7 MPa, 26,5 MPa, 26,6 MPa i 27,2 $\mathrm{MPa}$. Dla zapraw z 15\% granulatu gumowego wytrzymałość na ściskanie była następująca: $12,6 \mathrm{MPa}$ dla frakcji 0-0,08 mm, 16,5 MPa dla frakcji 0,6-2,0 mm, $18,1 \mathrm{MPa}$ dla frakcji $1-4 \mathrm{~mm}$ i $18,5 \mathrm{MPa}$ dla frakcji 2,5-6 mm.

Table 7. Compressive strength of CEM IV/B $(V) 32.5 \mathrm{~N}$ mortars with rubber granules Tabela 7. Wytrzymałość na ściskanie zapraw CEM IV/B(V) 32,5 N z granulatem gumowym

\begin{tabular}{|c|c|c|c|}
\hline \multirow{2}{*}{ Test results } & \multicolumn{3}{|c|}{ Compressive strength [MPa] } \\
\hline & 2 days & 7 days & 28 days \\
\hline CEM IV/B-V $32.5 \mathrm{~N}$ & $18.2 \pm 0.3$ & $28.4 \pm 0.6$ & $40.3 \pm 0.5$ \\
\hline CEM IV/B(V) 32.5 N 5\% 0-0.08 mm & $14.4 \pm 0.5$ & $21.1 \pm 0.4$ & $31.1 \pm 0.5$ \\
\hline CEM IV/B(V) 32.5 N $5 \% 0.6-2 \mathrm{~mm}$ & $14.2 \pm 0.3$ & $22.3 \pm 0.5$ & $32.2 \pm 0.8$ \\
\hline CEM IV/B(V) 32.5 N 5\% 1-4 mm & $14.3 \pm 0.5$ & $24.0 \pm 0.5$ & $31.6 \pm 1.0$ \\
\hline CEM IV/B(V) 32.5 N 5\% 2.5-6 mm & $14.0 \pm 0.4$ & $23.4 \pm 0.8$ & $32.2 \pm 0.7$ \\
\hline CEM IV/B(V) 32.5 N 15\% 0-0.08 mm & $8.2 \pm 0.2$ & $13.6 \pm 0.3$ & $18.1 \pm 0.5$ \\
\hline CEM IV/B(V) 32.5 N 15\% 0.6-2 mm & $9.1 \pm 0.1$ & $14.6 \pm 0.5$ & $20.5 \pm 0.6$ \\
\hline CEM IV/B(V) 32.5 N 15\% 1-4 mm & $9.5 \pm 0.5$ & $15.3 \pm 1.1$ & $21.1 \pm 0.5$ \\
\hline CEM IV/B(V) 32.5 N 15\% 2.5-6 mm & $9.6 \pm 0.3$ & $15.2 \pm 0.5$ & $22.4 \pm 0.6$ \\
\hline
\end{tabular}

The strength of the mortar based on CEM IV/B(V) $32.5 \mathrm{~N}$ cement after 2,7 and 28 days was $18.2 \mathrm{MPa}$, 28.4 $\mathrm{MPa}$ and 40.3 $\mathrm{MPa}$. The highest strength after 28 days was obtained for CEM IV/B(V) 32.5 N 5\% 0.6-2 $\mathrm{mm}$ and was $32.2 \mathrm{MPa}$. The same value was obtained for CEM IV/B(V) 32.5 N 2.5-6.0. The lowest strength after 28 days was obtained for CEM IV/B(V) 32.5 N 5\% 0-0,8 mm mortar (31.1 MPa). After 28 days the compressive strength of the tests with $15 \%$ rubber granules was lower than that of the reference mortar strength by 22.2 MPa (CEM IV/B(V) $32.5 \mathrm{~N} \mathrm{15 \%}$ 0-0.8 mm), 19.8 MPa (CEM IV/B(V) $32.5 \mathrm{~N} 15 \%$ 0.6-2 mm), 19.2 MPa (CEM IV/B(V) 32.5 N 5\% 1-4 $\mathrm{mm})$ and $17.9 \mathrm{MPa}$.

An example of a microstructure with X-ray microanalysis of cement mortar (CEM II B-V 32.5 R) with rubber granules of $1.0-4.0 \mathrm{~mm}$ grain-size is shown in Figures 1a-1c.
Wytrzymałość zaprawy na bazie cementu CEM IV/ B(V) 32,5 N po 2, 7 i 28 dniach była następująca: 18,2 MPa, 28,4 MPa i 40,3 MPa. Najwyższą wytrzymałość po 28 dniach uzyskano dla próby CEM IV/B(V) 32,5 N 5\% 0,6-2 mm, która wyniosła 32,2 MPa. Tę samą wartość uzyskano dla zaprawy CEM IV/B(V) 32,5 N 2,5-6,0. Najniższą wytrzymałość po 28 dniach otrzymano dla zaprawy CEM IV/B(V) 32,5 N 5\% 0-0,8 mm (31,1 MPa). Wytrzymałość na ściskanie dla prób $\mathrm{z}$ dodatkiem $15 \%$ granulatu gumowego po 28 dniach była niższa od wytrzymałości zaprawy odniesienia o 22,2 MPa (CEM IV/B(V) 32,5 N 15\% 0-0,8 mm), 19,8 MPa (CEM IV/B(V) 32,5 N 15\% 0,6-2 mm), 19,2 MPa (CEM IV/B(V) 32,5 N 5\% 1-4 mm) i 17,9 MPa.

Przykładowa mikrostruktura wraz z mikroanalizą rentgenowską zaprawy cementowej (CEM II B-V $32,5 \mathrm{R}) \mathrm{z}$ granulatem gumowym o frakcji 1,0-4,0 mm została przedstawiona na rysunkach $1 \mathrm{a}-1 \mathrm{c}$. 

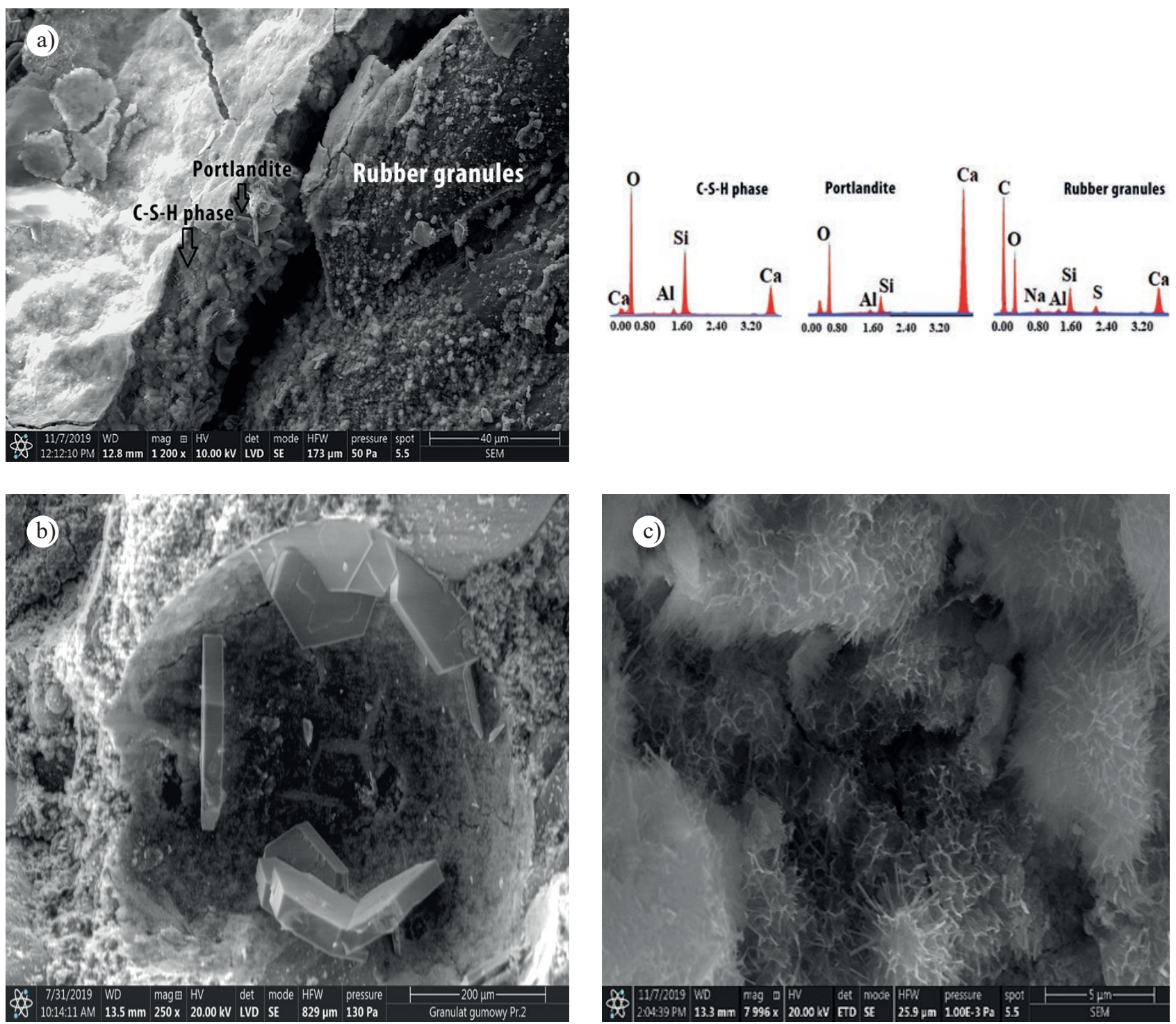

Fig. 1. Microstructure of cement mortars with rubber granules: a) contact zone cement paste-rubber granules, b) phase $\mathrm{C}-\mathrm{S}-\mathrm{H}, \mathrm{c}$ ) portlandite

Rys. 1. Mikrostruktura zapraw cementowych z granulatem gumowym: a) strefa kontaktowa zaczyn-granulat gumowy, b) faza $\mathrm{C}-\mathrm{S}-\mathrm{H}, \mathrm{c})$ portlandyt

Figure 1 shows the mortar microstructure with rubber granules. In the cement paste-rubber granules contact layer (Fig. 1a) higher amounts of portlandite are observed (Fig. 1b). The presence of this phase is associated with a locally higher $\mathrm{W} / \mathrm{C}$ ratio. The addition of rubber granules to the cement mortar does not affect the formation of C-S-H phase (Fig. 1c). This phase is characterized by a fibrous structure in the tested samples.

\section{SUMMARY}

The use of rubber granules as a substitute for cement provides interesting results. Taking into account the environmental aspect, the granules are disposable.
Na rysunku 1 przedstawiono mikrostrukturę zaprawy $\mathrm{z}$ dodatkiem granulatu gumowego. W warstwie kontaktowej zaczyn-granulat gumowy (rys. 1a) obserwuje się większe ilości portlandytu (rys. 1b). Obecność tej fazy związana jest z lokalnie większym współczynnikiem W/C. Dodatek granulatu gumowego do zaprawy cementowej nie wpływa na powstawanie fazy C-S-H (rys. 1c). Faza ta charakteryzuje się w badanych próbkach strukturą włóknistą.

\section{PODSUMOWANIE}

Zastosowanie granulatu gumowego jako zamiennika cementu daje interesujące wyniki. Biorąc pod uwagę aspekt ekologiczny, zastosowanie granulatu 
The use of $5 \%$ rubber granules in mortars resulted in a reduction of strength by about $20 \%$ in relation to the reference mortar for all tested cements. Obtained results of cement mortar compressive strength tests are lower than those given in the literature. Ganjian et al. [4] report that the use of ground tyres as a 5\% replacement for cement results in a 5\% reduction in strength.

Preliminary tests were limited to two levels of 5\% and $15 \%$ of rubber granules addition as a substitute for cement. The use of $15 \%$ rubber waste in all mortars results in a $50 \%$ reduction of strength in all mortars, which disqualifies them from further testing. The mortar microstructure tests with the addition of rubber granules of 1-4 mm grain-size showed that the use of rubber granules does not disturb the formation of the C-S-H phase, which is characterized by a fibrous structure. Increased portlandite content occurs in the cement paste-rubber granules contact layer. daje możliwość jego utylizacji. Użycie 5\% granulatu gumowego w zaprawach spowodowało obniżenie wytrzymałości o około $20 \% \mathrm{w}$ stosunku do zaprawy odniesienia dla wszystkich badanych cementów. Otrzymane wyniki badań wytrzymałości na ściskanie zapraw cementowych są niższe niż podaje literatura. Ganjian i inni [4] podają, że zastosowanie rozdrobnionych opon jako zamiennika cementu w ilości 5\% powoduje spadek wytrzymałości o 5\%.

Badania wstępne ograniczyły się do dwóch poziomów $5 \%$ i $15 \%$ dodatku granulatu gumowego jako zamiennika cementu. Zastosowanie 15\% odpadu gumowego powoduje we wszystkich zaprawach spadek wytrzymałości o $50 \%$, co dyskwalifikuje je w dalszych etapach badań. Badania mikrostruktury zaprawy z dodatkiem granulatu gumowego o frakcji 1-4 mm wykazały, że zastosowanie granulatu gumowego nie zaburza powstawania fazy C-S-H, która charakteryzuje się strukturą włóknistą. Zwiększona zawartość portlandytu występuje w warstwie kontaktowej zaczyn-granulat gumowy.

\section{REFERENCES}

[1] Horodecka R., Kalabińska M., Piłat J., Radziszewski P., Sybilski D.: Wykorzystanie zużytych opon samochodowych w budownictwie drogowym. IBDiM, Warszawa, 2002.

[2] Sybilski D.: Zastosowanie odpadów gumowych w budownictwie drogowym, Przegląd Budowlanym, 80(5), 2009, 37-44.

[3] Journal of Laws of 2013, item 21 Act of 14 December 2012 on waste.

[4] Ganjian E., Khorami M. and Maghsoudi A.A.: Scrap- Tire-Rubber Replacement Foraggregate and Filler in Concrete, Construction and Building Materials, Vol. 23, No. 5, 2009, 1828-1836.

[5] Batayneh M.K., Iqbal M. and Ibrahim A.: Promoting the Use of Crumb Rubber Concrete in Developing countries, Waste Management, Vol. 28, No. 11, 2008, pp. 2171- 2176.

[6] Topcu I.B. and Demir A.: Durability of Rubberized Mortar and Concrete, ASCE Journal of Materials in Civil Engineering, Vol. 19, No. 2, 2007, pp. 173-178.doi:10.1061/(ASCE)0899-1561(2007)19:2(173).

[7] Hernandez-Olivares F. and Barluenga G.: Fire Perfor- mance of Recycled Rubber-Filled High-Strength Con- crete, Cement and Concrete Research, Vol. 34, No. 1, 2004, pp. 109-117. doi:10.1016/S0008-8846(03)00253-9.

[8] Pierce C.E. and Blackwell M.C.: Potential of Scrap Tire Rubber as Lightweight Aggregate Inflowable Fill, Waste Management, Vol. 23, No. 3, 2003, pp. 197-208.

[9] Sgobba S., Marano G.C., Borsa M. and Molfetta M.: Use of Rubber Particles from Recycled Tires as Con-crete Aggregate for Engineering Applications, Coventry University and The University of Wisconsin Milwaukee Centre for By-Products Utilization, 2nd International Conference on Sustainable Construction Materials and Technologies, Ancona, 28-30 June 2010, 11 p.

[10] Boudaoud Z., Beddar M.: Effects of Recycled tires rubber aggregates on the characteristic of cement concreto, Open Journal of civil Engineering, 2012,2,193-197.

[11] Benazzouk A., Mezreb K., Doyen G., Goullieux A. and Quéneudec M.: Effect of Rubber Aggregates on the PhysicoMechanical Behavior of Cement-Rubber Com- posites-Influence of the Alveolar Texture of Rubber Ag-gregates, Cement and Concrete Composites, Vol. 25, No. 7, 2003, pp. 711-720.doi:10.1016/S0958-9465(02)00067-7.

[12] Benazzouk A., Douzane O. and Quéneudec M.: Trans- port of Fluids in Cement-Rubber Composites, Cement and Concrete Composites, Vol. 26, No. 1, 2004, pp. 21-29. doi:10.1016/S0958-9465(02)00119-1.

[13] Topçu U. B.: The Properties of Rubberized Concrete, Cement and Concrete Research, Vol. 25, No. 2, 1995, pp. 304310. doi:10.1016/0008-8846(95)00014-3.

\section{Acknowledgments:}

This work was supported by Ministry of Science and Higher Education, Grant No. 3NS20K18/3NS17K19 - The Lukasiewicz Research Network- Institute of Ceramics and Building Materials, Division of Glass and Building Materials in Cracow

\section{Podziękowania:}

Praca finansowana przez Ministerstwo Nauki i Szkolnictwa Wyższego, praca statutowa nr 3NS20K18/3NS17K19 Instytut Ceramiki i Materiałów Budowlanych, Oddziat Szkła i Materiałów Budowlanych w Krakowie 